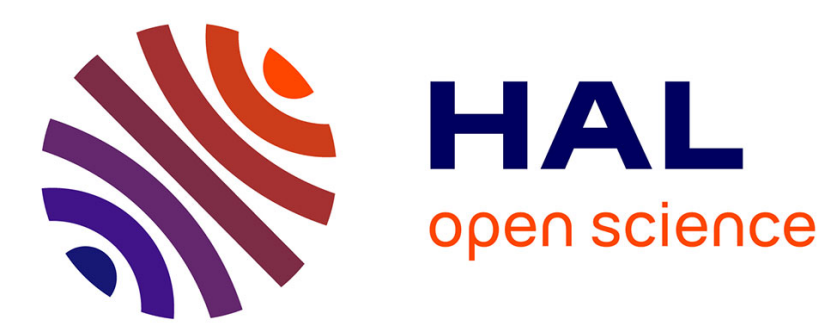

\title{
ECONOMIC GROWTH IN A WORLD OF IDEAS: THE US AND THE LEADING EUROPEAN COUNTRIES
}

Rafael L. Myro, Alberto Colino, Patricio Pérez

\section{- To cite this version:}

Rafael L. Myro, Alberto Colino, Patricio Pérez. ECONOMIC GROWTH IN A WORLD OF IDEAS: THE US AND THE LEADING EUROPEAN COUNTRIES. Applied Economics, 2008, 40 (22), pp.2901-2909. 10.1080/00036840600993957 . hal-00581995

\section{HAL Id: hal-00581995 \\ https://hal.science/hal-00581995}

Submitted on 1 Apr 2011

HAL is a multi-disciplinary open access archive for the deposit and dissemination of scientific research documents, whether they are published or not. The documents may come from teaching and research institutions in France or abroad, or from public or private research centers.
L'archive ouverte pluridisciplinaire HAL, est destinée au dépôt et à la diffusion de documents scientifiques de niveau recherche, publiés ou non, émanant des établissements d'enseignement et de recherche français ou étrangers, des laboratoires publics ou privés. 


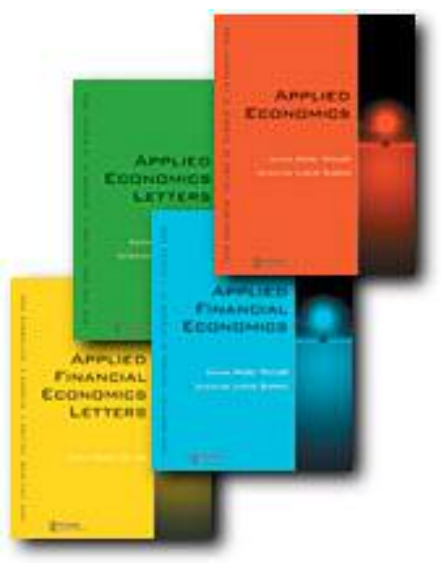

ECONOMIC GROWTH IN A WORLD OF IDEAS: THE US AND THE LEADING EUROPEAN COUNTRIES

\begin{tabular}{|r|l|}
\hline Journal: & Applied Economics \\
\hline Manuscript ID: & APE-05-0532.R1 \\
\hline Journal Selection: & Applied Economics \\
\hline JEL Code: & $\begin{array}{l}\text { O10 - General < O1 - Economic Development < O - Economic } \\
\text { Development, Technological Change, and Growth, O40 - General < } \\
\text { O4 - Economic Growth and Aggregate Productivity < O - Economic } \\
\text { Development, Technological Change, and Growth, O33 - } \\
\text { Processes < O3 - Technological Change|Research and Development } \\
<\text { O - Economic Development, Technological Change, and Growth, } \\
\text { O30 - General < O3 - Technological Change|Research and } \\
\text { Development < O - Economic Development, Technological Change, } \\
\text { and Growth }\end{array}$ \\
\hline Keywords: & $\begin{array}{l}\text { GROWHT , TOTAL FACTOR PRODUCTIVITY, TECHNICAL PROGRESS, } \\
\text { IDEAS FUNCTION }\end{array}$ \\
\hline \hline
\end{tabular}

powered by ScholarOne
Manuscript Central 


\section{ECONOMIC GROWTH IN A WORLD OF IDEAS: THE US AND THE LEADING EUROPEAN COUNTRIES}

\section{Introduction}

With the introduction of an ideas function, Paul Romer started an interesting new line of research in economic growth models (Romer, 1990). After some useful changes in Romer's original specification to make it more generally applicable, Charles Jones performed a growth accounting exercise for the US economy along the 1950-1993 period that contained at least two innovative contributions (Jones, 2002). The first was to relate Solow's residual path in the US to the number of scientists and technicians in the five countries concentrating the main weight of world tech's innovation (US, UK, Germany, France and Japan, a group defined by the above-mentioned author as G-5). The second was to distinguish between the part of the residual that can be attributed to the increase of population in a stationary state (and consequently the number of scientists and technicians, which is assumed to increase proportionally) and the part that can be assigned to the transition towards such a state.

Considering this line of research to be of great interest, we extend here the application of Romer's and Jones' ideas functions specifications to the three European Countries integrating the G-5 Group, Germany, France and the United Kingdom, trying to offer a explanation of the evolution of the aggregate multifactor productivity in them. However, as these economies are technologically dependent to a certain extent, at least from the US, our purpose require mainly to focus in the mechanisms that capture the international dissemination of scientific knowledge as much as this proposed by Jones seems too simple even for the technologically more independent economies as it is that of the US. In fact, we show that the introduction of a catching-up process to a technological frontier improves the model for the European economies. The convenience of such an approach was already suggested years ago by Nelson and Phelps (1966) and more recently by Barro and Sala i Martin (1997) and either have implicit or explicitly been assumed in the empirical works by Coe and Helpman (1995), De La Fuente (1995), Engelbrecht (1997) or Bils and Klenow (2000). 
Therefore, in the following pages we first expose and apply to Germany, France and the United Kigdom Romer's and Jones' ideas function specifications to afterward propose and estimate a new one which introduce a catching up process in technological knowledge.

\section{Technical progress and scientific knowledge in the leading European countries compared to the US.}

Jones' generalization of the ideas function originally proposed by Romer adopts the following form in its discrete time version (Jones, 1995, 2002):

$\Delta A_{t+1}=\delta H_{A t}^{\lambda} A_{t}^{\phi}$

$A_{0}>0 ; \delta>0,0<\lambda \leq 1 ; \phi<1$

Where $A$ is the ideas stock, $H_{A}$ is the world research effort in the production of $A$, and $\delta$ is a parameter to measure the degree of dissemination.

Jones (2002) approaches the value $A_{t}$ through the observed multi-factor productivity (TFP) ${ }^{1}$ and $H_{A}$ as the sum of the number of researchers in the G-5 countries, assuming that the human capital they embody is the same in all those countries.

To be able to carry out the OLS estimation, expressing $A$ in a more handled way, and obviating as far as possible the fact that the time series of both $H_{A t}$ and $A_{t}$ are non stationary clearly exhibiting increasing trends, he divides [1] by $A_{t}$, which allows him to express the first term in annual change rates, in the following way:

$$
\frac{\Delta A_{t+1}}{A_{t}}=\delta\left[\frac{H_{A t}}{A_{t}^{1 / \gamma}}\right]^{\lambda}
$$

\footnotetext{
${ }^{1}$ Following Jones, $A_{t}$ is a latent unobservable variable defining the technological frontier. The total factor productivity (TFP) of the US economy is suppose to fit this frontier with some measurement error, i.e. making $\log T F P_{t}=\log A_{t}+\varepsilon_{t}$, where $\varepsilon$ is the measurement error term.
} 
Where $\gamma=\frac{\lambda}{1-\phi}$. Then he log-linearizes the resulting equation [2] around a path where both the value of $A_{t}$ measured through the TFP, and that of $H_{A t}$, grow at constant rates, obtaining a standard error-correction model with the following form:

$\Delta \log A_{t+1} \approx \beta_{0}+\lambda g_{A}\left(\log H_{A t}-\beta_{2} \log A_{t}\right)+\eta_{t+1}$

Were $\beta_{0} \equiv g_{A}\left(1-\log \left(g_{A} / \delta\right)\right)$ is a constant, $g_{A}$ is the rate of growth of $A$ and $\eta_{t+1} \equiv \Delta \varepsilon_{t+1}+\frac{\lambda g_{A}}{\gamma} \varepsilon_{t}$ is a error term. $\beta_{2}$ is equal to $1 / \gamma$ and the parameter $\gamma$ is obtained from the linear tendency in the logarithm of $H_{A t}$ and $A_{t}$, working then as an integration parameter which could also be approximated by the ratio between the rates of growth of the two mentioned variables ${ }^{2}$.

From the three coefficients of the log-linearized equation, $\beta_{0}, \lambda$ and $\beta_{2}$, the implicit values of $\gamma$ and $\phi$ are derived, so we have all the relevant coefficients of the original ideas function.

Table 1 shows the results of the estimates of [3] for Germany, France and the United Kingdom, for the period 1950-1999, which also includes Jones' results for the US referred to the period 1950-1993, without imposing any value for $\lambda$. Our own estimation for the US is also shown, taking in the longer period between 1950 and 2001. Appendix 1 details the sources of the data and of the methods employed in their processing.

[Table1]

The results obtained for the three G-5 countries are in line with those for the US. The values of $\lambda$ are somewhat lower for the European countries, but clearly higher than 1 , contrary to what was expected, which seems to reveal the problems of non stationarity

\footnotetext{
${ }^{2}$ This parameter $\gamma$ is supposed to be more faithful than $\lambda$. In fact, Jones (2002) obtains implausible values for $\lambda$ in his estimates, much higher than 1 , as these are not driven by time trends and so the OLS estimators are subject to bias because of measurement error and endogeneity. So he opts for imposing values to $\lambda$ along a justifiable range, from 0.25 to 1 , deriving from them a spectrum of estimates for $\gamma$ that presumably must include its true value.
} 
and endogenity signaled by Jones. $\phi$ 's values are always negative, but not greatly so in the cases of Germany and France, where the $\mathrm{R}^{2} \mathrm{~s}$ are higher. It is worth pointing out as well that the parameter values obtained for the UK have more in common with their US equivalents than with the values for the other European countries. Finally, the inclusion in the estimation for the US of the years corresponding to the productivity boom does not significantly alter the value of the coefficients obtained for that country, as might have been supposed given the short length of the time period added. It seems that this boom will only prove to be important in the long term if it shows continuity over the coming years.

Whatever the case, these results tend to underline the goodness of fit of Romer's model and of the specification adopted by Jones. Of course, the points made above regarding the robustness of $\lambda$ and $\gamma$ should not be ignored. Nevertheless here we are more interested in checking out the elementary mechanism of the international dissemination of knowledge implicit in the model (the scientists and technicians in the remaining G-5 countries), because, from the results obtained, it could be easily proved that the European countries would never attain technological convergence with the US, even if a similar proportion of the population were employed in research activities, now standing at around 1 per cent. This result might be partially due to the scale effect on $H$ that is implicit in the ideas function, or to limits on the international dissemination of knowledge. However, it could also be a consequence of the model's failure to capture the influence of ideas from abroad, given the absence of explicit variables to measure the relative technological backwardness of the European countries. It is advisable, then, to introduce a technological catch-up term in order to show convergence towards the technological frontier, as suggested by several authors already quoted.

To explore this last possibility, we tested the real contribution of researchers working in different countries, after which we concluded that, in the estimations carried out, only those scientists and technicians working in each country are significant. The introduction of scientists working in the other G-5 countries does not alter the results obtained with this crucial variable. If this is true for Germany, France and Great Britain $^{3}$, it is even more so in the case of the US, the leading generator of ideas within

\footnotetext{
${ }^{3}$ The detailed results are available from the authors upon request.
} 
the G-5. Thus, as it can be observed in Table 2, if, in the estimation of Jones' original ideas function for the US (expression [1]), the number of scientists in the remaining G-5 countries is introduced gradually and separately, the coefficients obtained for them all are statistically insignificant.

\section{[Table 2]}

The conclusion seems clear: the mechanism for the international dissemination of ideas considered by the reference model is not suitable even for the leading country. Therefore, if this deficiency was overcome the model would be capable of providing better results, above all when technologically dependent European countries are concerned. We try to do this in the following section.

But, before coming to that, we feel it would be helpful to illustrate the technological backwardness of European countries through Figure 1, which registers "research intensity" in each country, defined as the proportion of scientists and technicians in relation to total employment. Only recently have Germany and France approached the levels reached by the ratio quoted for the US, to a large degree as a consequence of the latter's very appreciable slowdown in growth from the mid-1960s onwards. Nevertheless, in the 1990s the United States once again leapt ahead of the technological leaders of Europe in this area. But even if the ratios displayed by the US and Europe had been closer, it seems undeniable that, just as the models by Romer and Jones suppose, the volume of new ideas depends on the number of scientists, not merely on their proportion of the working population.

\section{[Figure 1]}

It is also interesting to point out that the variable employed here to measure the R\&D activity, the number of researchers, $H_{A t}$, seems to be very close in its time evolution to another more commonly chosen, the stock of technological capital ${ }^{4}$. To verify this, we took the calculations of this last mentioned variable by Martín and Velázquez (2001), arrived at using real R\&D expenditure and the permanent inventory method, assuming a given rate of depreciation. Then we calculated the technological capital indicator per

\footnotetext{
${ }^{4}$ Bönte (2003) shows that a long run relation between productivity and R\&D capital stock exists in the US economy. Nevertheless, through an application to the Italian economy, Atella and Quintieri (2001) show that this relationship depend on the measures of Solow's residual and on the aggregation level of the analysis.
} 
researcher (scientists and technicians) that show to be largely constant in the long run (Figure 2), indicating parallel evolutions of capital and people involved in research activities.

[Figure 2]

What proves surprising about the indicator constructed for technological capital per worker is that it registers lower values for the US and UK than for Germany and France, perhaps due to differences in the relative wages of researchers measured in common currency. Actually, such result seems to encourage the use of the number of researchers as indicator of the dimension of $\mathrm{R} \& \mathrm{D}$ activities, particularly in international comparisons.

\section{A technological frontier convergence model for the leading European countries}

On the basis of the aforementioned research works on technological international spillovers, a more general model may be formulated for any technologically dependent country, taking one country or a group of leading countries as the technological frontier, $l$.

$$
\Delta A_{t+1}=\delta H_{A t}^{\lambda} A_{l t}^{\mu} A_{t}^{(\phi-\mu)}
$$

where the increase of ideas stock for the technologically dependent country during the period $t+1$ depends on its value in $t$ and on the value in that same year of the ideas stock of the country considered to be on the technological frontier, $l$, as well as the number of researchers $H_{A}$ in the country in time t. Following Jones' intuition, in expression [4] we do not impose constant returns to scale in the ideas stocks. To do that we would have to make $\phi=1$. In our estimates, we explore the importance of such restriction.

If the country being studied is also the leader in technology, i.e. if it is the $l$ country, the previous expression is simplified and becomes transformed as follows: 
$\Delta A_{t+1}=\delta H_{A t}^{\lambda} A_{t}^{\phi}$

which is the formulation suggested by Jones, a particular case of the more general model posed here. When $\phi=1$ we have the more restricted model by Romer. In terms of rates of variation, the above expression adopts this form:

$\frac{\Delta A_{t+1}}{A_{t}}=\delta H_{A t}^{\lambda} A_{t}^{\phi-1}$

In the Romer case, as $\phi=1$, a direct relationship is established between the growth rates of $A$ and $H$, where the scale effect on $H$ is more evident.

If the country under study does not happen to be the leader, the corresponding expression is:

$$
\frac{\Delta A_{t+1}}{A_{t}}=\delta H_{A t}^{\lambda}\left(\frac{A_{l t}}{A_{t}}\right)^{\mu} A_{t}^{\phi-1}
$$

in which the growth rate of $A$ depends directly on $H$ and on the technological distance from the leader, captured by the ratio $A_{t, l} / A_{t}$, where $\mu$ becomes a coefficient to measure the speed of convergence towards the technological frontier. It also depends on the stock of knowledge at the technological frontier, which is wider than the domestic stock.

To make the estimation procedure easier, equation [4] may be expressed in absolute values of $A$ :

$$
A_{t+1}=\delta H_{A t}^{\lambda} A_{l t}^{\mu} A_{t}^{(\phi-\mu)}
$$

As De la Fuente points out (2002), this expression has similar implications to that by Jones in the long run. Both of them require a value of $\phi$ equal to 1 to find a steady state 
with a constant and strictly positive rate of technical progress given a constant value of $H$.

Taking logarithms in [5]:

$\log A_{t+1}=\log \delta+\lambda \log H_{A t}+\mu \log A_{l t}-\mu \log A_{t}+\phi \log A_{t}$

or

$\log A_{t+1}-\log A_{t}=\log \delta+\lambda \log H_{A t}+\mu\left[\log A_{l t}-\log A_{t}\right]+(\phi-1) \log A_{t}$

and in a more simplified way:

$\Delta \log A_{t+1}=\log \delta+\lambda \log H_{A t}+\mu\left[\log A_{l t}-\log A_{t}\right]+(\phi-1) \log A_{t}$

The values of elasticities $\lambda$ and $\phi$ no longer coincide with those in the original model of Jones, where the dependent variable is the variation of $A$. But it can be easily proved that the value of $\lambda$ in Jones' model is equal to that obtained in [6] multiplied by $\left(1+\frac{1}{g}\right)$, where $g$ is the rate of variation of $A$ (De la Fuente, 2002) ${ }^{5}$.

In estimating this model, we discovered a high negative correlation between $A_{t}$ and $\log A_{t l}-\log A_{t}$, generating problems of multi-collinearity and hence difficulting calculation of parameters' true values. We decided, therefore, to carry out the estimation in two stages. First, we imposed the restriction of constant returns to scale $(\phi-1)=0$, just to estimate the values of $\lambda$ and $\mu$; then we used the residuals obtained in the estimation to calculate the value of the coefficient $\phi$, regressing them on the log values of home ideas stock.

\footnotetext{
${ }^{5}$ Similarly $\phi$ in Jones' model correspond in [6] to $(\phi-1) / \mathrm{g}$.
} 
Table 3 offers the first set of estimations for Germany, France and the United Kingdom, assuming that the US defines the technological frontier they tend towards. The estimation is made jointly for them all, using the SUR method, testing the introduction of different restrictions on the parameters. Constant returns to scale in the foreign stock of ideas are assumed at this first stage.

\section{[Table 3]}

The first estimation, in which a common $\delta$ is imposed and for the catch-up coefficient, $\mu$, offers positive results. The value of $\mathrm{R}^{2}$ is high and the values of $\lambda$ and $\mu$ are significant, except in the case of the UK. The values for $\lambda$ prove to be lower than in Jones' original model, but are not comparable to them as was explained above. The comparable values for Germany, France and the United Kingdom would be, respectively, $0.56,0.65$ and 0.65 , a result very much in line with what would be expected from the theoretical model. The speed of convergence towards the frontier is always in excess of 8 per cent, and frequently reaches levels around 15 per cent, guaranteeing convergence with the US in the stationary state, particularly for Germany. When the parameter equality restrictions are removed, the results are worse for France, since $\mu$ does not prove significant, and for the United Kingdom, which obtains a negative value of $\lambda$. However, in this scenario, the values of this coefficient grow for Germany and France. When the equality restriction is imposed only on the values of $\delta$, the results of the estimation improve for France but not for the UK.

However, the estimates forecast higher TFP than that registered for recent years, leading us to think that perhaps the model performs better avoiding the restriction of constant returns of scale, following Jones' intuition. Nevertheless, when we approach the value of $\phi-1$, using the residuals of the estimations already made, we get a negative and significant value for it only in the case of Germany, as shown in table 4. The estimate for that country is also robust to autocorrelation, following the standard Rao test for an error component model (Bera, Escudero and Yoon, 2000). Anyway, the value obtained for Germany is very small, possibly indicating that $\phi$ could be close to 1 .

[Table 4] 
Figure 3 depict the best estimates for the three countries which fit well the true TFP values. The estimates are particularly good for Germany. An explanation for the decrease in TFP over recent years in Germany and France would seem to rely in the reduction of the external source of ideas, perhaps due to the fact that the European countries have gradually drawn closer to the US ideas stock and have slowly continued to do so. This might, however, be because barriers to the entry of foreign technologies have tended to be on the rise in both countries, as Parente and Prescott $(1993,2000)$ suggest, even more than in the United Kingdom where less barriers would have been kept permanently.

\section{[Figure 3]}

The conclusion is that the ideas model can be improved in this direction, at least for the technologically dependent countries, or, to put it another way, for all but the $\mathrm{US}^{6}$. Nonetheless, it is undeniable that the United States also benefits from ideas created elsewhere, although it is difficult to capture this effect at an empirical level, since this demands the calculation of a more complex technological frontier, a combination of various countries. In fact, this might be the reason for the limited explanatory capacity of the model, highlighted in the obtained $\mathrm{R}^{2}$, though that in itself does not detract from the positive features of this specification, about which we offer more arguments below.

\section{Conclusions}

In this paper we have discussed some of the results that emerge from the ideas production model that was originally formulated by Romer (1990), then generalized by Jones (1995) and later used by the same author to explain the behavior of TFP in the US (Jones, 2002). We have analyzed the application of the model to the countries at the forefront of technological research in Europe, i.e. Germany, France and the UK, as well as to the US for a longer time period than that considered by Jones.

\footnotetext{
${ }^{6}$ Naturally, a great deal of work remains to be done in various areas, ranging from improving data and extending their reach to other countries, to the specification of the model and its application to different time periods, taking into consideration the possibility of structural breaks in R\&D process in the mid 60s, as Pérez and Esteve (2006) show.
} 
We point out that Jones' empirical approach to capturing the international dissemination of ideas can be improved, as the TFP is completely dependent on each country's own scientists, both in Europe and in the US. Explicit consideration of the international circulation of ideas must involve the introduction of catch-up mechanisms in relation to a technological frontier. When this is done, the model seems to perform better and we observe that there is a process of convergence towards the technological frontier. In the explanation of the TFP evolution of some leading European countries, we have approached the distinction between the domestic creation of ideas from the capture of foreign ones. We have also made a first attempt to isolate the negative effect of the increased stock of ideas on the ability to discover new ones, adding new evidence to Jones' intuitive instinct.

To advance further in this area of research would require, in addition to more depurated data and better estimates, the introduction of variables to explain what determines an increases the speed of the catch-up process, paying attention to commercial flows and foreign investment, as vehicles of transmission, in line with suggestions contained in certain recent studies.

\section{References}

Atella, V. and B. Quintieri (2001) Do R\&D Expenditures Really Matter for TFP? , Applied Economics, 33, 1385-1389.

Barro, R. and J.W. Lee (2001) International Data on Educational Attainment: Updates and Implications, Oxford Economic Papers, 53, 541-563.

Barro, R.and X. Sala-i-Martin (1997) Technological Diffusion, Convergence and Growth, Journal of Economic Growth, 2, 1-26.

Bera, A.K.; W. Sosa Escudero and M. Yoon (2000) Test for the Error Component Model in the Presence of Local Misspecification, mimeo.

Bils, M. and P. Klenow (2000) Does Schooling Cause Growth ?, American Economic Review, 90,11601183.

Bonte, W. ( 2003) Does Federally Financed Business R\&D Matter for US Productivity Growth?, Applied Economics,35, 1619-1625.

Coe, D.T. and E. Helpman (1995) International R\&D Spillovers, European Economic Review, 39, 859-87.

De la Fuente, A. (1995) Catch-up, Growth and Convergence in the OECD, CEPR Discussion Paper, 1274. De la Fuente, A.and R. Doménech (2001) Schooling data, Technological Diffusion and the Neoclassical Model, American Economic Review, 91, Papers and Proceedings, 323-27.

De la Fuente, A.(2002) Coment to Myro and Pérez (2002), Moneda y Crédito, Segunda Época, 214, 249259.

Engelbrech, H.J. (1997) Internacional R\&D Spillovers, Human Capital and Productivity in the OECD Economies: an Empirical Investigation, European Economic Review, 41, 1479-88.

Harberger, A.C., D.L. Wisecarver (1977) Private and Social Rates of Return to Capital in Uruguay, Economic Development and Cultural Change, 25, 411-445. 
Nelson, R. and E. Phelps (1966) Investments in Humans, Technological Diffusion, and Economic Growth, American Economic Review, 56, 69-75.

Jones, Ch. (1995) R\&D Based Models of Economic Growth, Journal of Political Economy, 103, 759-784. Jones, Ch. I.(2002) Sources of U.S. Economic Growth in a World of Ideas, American Economic Review, 92, 220-39.

Maddison, A. (1995a) Explaining the Economic Performance of Nations: Essays in Time and Space, in Economists of the Twentieth Century Series, Aldershot, Hants: Edward Elgar.

(1995b) Monitoring the World Economy, 1820-1992,Organisation for Economic Cooperation and Development, Paris.

Martín, C.and F.J. Velázquez (2001) Serie de Indicadores de Convergencia Real para España, el Resto de los Países de la UE y EEUU, Fundación para las Cajas de Ahorros Confederadas, Madrid.

Myro, R. and P. Pérez (2002) Crecimiento en Europa y EEUU: los Determinantes del Progreso Técnico, Moneda y Crédito, Segunda Época, 214, 215-242.

Parente, S.L. and E.C. Prescott (1993) Barriers to Technological Adoptions and Development, The Journal of Political Economy, 102, 298-321.

Parente, S. L., and E. C. Prescott (2000) Barriers to Riches, MIT Press, Cambridge, MA.

Pérez, P. and V. Esteve (2006) Trend Breaks in the Research and Development Process, Applied Economics (forthcoming).

Romer, P.M. (1990) Endogenous Technological Change, Journal of Political Economy, 98, S 71-102.

\section{APPENDIX 1. DATA SOURCES}

- GDP per Hour. The data for GDP at constant prices for the 1990s were calculated using Eurostat (Statistical appendix to European Economy). The values corresponding to the period 1950-1960 are based on the GDP Movement series provided by Maddison (1995b). Weekly working hours in non-agricultural activities were obtained from the Work Statistics Directories, published by the International Labor Organization (ILO), whilst it was necessary to use various issues of the OECD Labour Force Statistics in order to estimate some of the values for the United Kingdom.

- Human Capital. The data for average years of educational training for the population sector over 25 years of age come from De la Fuente and Doménech (2001) and (in the case of Germany) from Barro and Lee (2001).

- Engineers and Scientists assigned to $R+D$ activities. The source is the same as in Jones (2002), though it was necessary to estimate for 1994-1999 using the exponential smoothing method. For the years prior to 1960, it was assumed that the ratio of "research intensity" for each of the three European countries in relation to the US was the same in 1950 as in 1960. This ratio was interpolated for the intermediate years. To obtain the number of scientists and technicians a multiplication was made based on employment. 
- Labour force. The starting point is the total employment in 1960, obtained from OECD Labour Force Statistics. The series for the following years was obtained by applying to that number the rates of variation provided by Eurostat, in European Economy. In contrast, the series for the preceding years, 1950-1960, is the result of deducting the annual variations provided by Maddison (1995b) from the number of people employed in 1960.

- Physical Capital. Fixed capital stock was calculated by means of the perpetual inventory method, obtaining the initial value of capital stock following the approach of Harberger and Wisecarver (1977). The depreciation rate used was 4 per cent. For the years between 1950 and 1960, the annual variation rates provided by Maddison (1995a) were applied to the value estimated for 1960 .

- Investment. Gross Capital Investment at 1990s constant prices was calculated from Eurostat (European Economy Appendix). The values for 1950-1960 were calculated using the variation rates provided by Madison (1995a). 
Table 1. Estimation of the ideas function for 1950-1999

Estimates of the equation [3]. Log-linearized model

The dependent variable is $\Delta \log A_{t+1}$

\begin{tabular}{lrrrrrr}
\hline Country & $\beta_{0}$ & $\lambda$ & $\beta_{2}$ & $\gamma_{\text {implicit }}$ & $\mathrm{R}^{2}$ & $\phi_{\text {implicit }}$ \\
\hline Germany & -0.303 & 2.309 & 1.946 & 0.514 & 0.597 & -3.49 \\
& $(.181)$ & $(1.008)$ & $(, 281)$ & $(.074)$ & & \\
France & -0.099 & 1.270 & 2.376 & 0.421 & 0.385 & -2.02 \\
& $(.106)$ & $(.764)$ & $(.639)$ & $(.113)$ & & \\
United Kingdom & -0.107 & 3.956 & 3.322 & 0.301 & 0.123 & -12.12 \\
& $(.052)$ & $(1.190)$ & $(.487)$ & $(.044)$ & & \\
US (1950-1993) & 0.022 & 4.536 & 3.647 & 0.274 & 0.218 & -15.63 \\
& $(.036)$ & $(1.476)$ & $(.295)$ & $(.022)$ & & \\
US (1950-01) & -0.004 & 3.697 & 3.385 & 0.295 & 0.130 & -12.69 \\
& $(.037)$ & $(1.479)$ & $(.306)$ & $(.027)$ & & \\
\hline
\end{tabular}

Newey-West standard errors, robust to heterokedasticity and autocorrelation, in brackets. The first estimation for the US is that carried out by Jones. 
Table 2: Ideas function estimation for US (researches and scientists $\left(H_{A t}\right)$ from each of the G-5 countries)

Estimates of the equation [1]

The dependent variable is $\log \left(\Delta A_{t+1}\right)$

\begin{tabular}{|c|c|c|c|c|c|}
\hline & (1) & (2) & (3) & (4) & (5) \\
\hline$\beta_{0}$ & $\begin{array}{l}-0.004 \\
(.004)\end{array}$ & $\begin{array}{l}-0.004 \\
(.003)\end{array}$ & $\begin{array}{l}-1.011 \\
(7.50)\end{array}$ & $\begin{array}{l}0.030 \\
(.005)\end{array}$ & $\begin{array}{l}0.043 \\
(.013)\end{array}$ \\
\hline $\log (\delta)$ & $\begin{array}{r}-2.300 \\
(.108)\end{array}$ & $\begin{array}{r}-2.250 \\
(.173)\end{array}$ & $\begin{array}{r}-5.558 \\
(16.12)\end{array}$ & & \\
\hline$\lambda_{G E R}$ & $\begin{array}{l}2.174 \\
(.150)\end{array}$ & $\begin{array}{l}1.964 \\
(.152)\end{array}$ & $\begin{array}{r}7.319 \\
(24.05)\end{array}$ & $\begin{array}{l}0.000 \\
(.000)\end{array}$ & $\begin{array}{r}0.000 \\
(.000)\end{array}$ \\
\hline$\lambda_{F R A}$ & $\begin{array}{l}0.251 \\
(.226)\end{array}$ & $\begin{array}{l}1.020 \\
(.236)\end{array}$ & $\begin{array}{r}-0.050 \\
(21.67)\end{array}$ & $\begin{array}{l}0.000 \\
(.000)\end{array}$ & $\begin{array}{l}0.000 \\
(.000)\end{array}$ \\
\hline$\lambda_{J A P}$ & $\begin{array}{l}4.176 \\
(.211)\end{array}$ & $\begin{array}{l}3.902 \\
(.179)\end{array}$ & $\begin{array}{r}4.920 \\
(11.06)\end{array}$ & $\begin{array}{l}0.000 \\
(.000)\end{array}$ & $\begin{array}{l}0.000 \\
(.000)\end{array}$ \\
\hline$\lambda_{U K}$ & $\begin{array}{l}0.679 \\
(.097)\end{array}$ & $\begin{array}{l}1.264 \\
(.216)\end{array}$ & $\begin{array}{r}1.012 \\
(11.07)\end{array}$ & $\begin{array}{l}0.000 \\
(.000)\end{array}$ & $\begin{array}{l}0.000 \\
(.000)\end{array}$ \\
\hline$\lambda_{U S A}$ & $\begin{array}{r}10.771 \\
(.099)\end{array}$ & $\begin{array}{r}10.798 \\
(.204)\end{array}$ & & & \\
\hline$\phi$ & $\begin{array}{r}-10.772 \\
(.132)\end{array}$ & $\begin{array}{r}-11.166 \\
(.249)\end{array}$ & $\begin{array}{c}-4.012 \\
(6.43)\end{array}$ & & \\
\hline $\operatorname{AR}(1)$ & & $\begin{array}{l}0.864 \\
(.073)\end{array}$ & & & $\begin{array}{l}0.772 \\
(.099)\end{array}$ \\
\hline$\Delta A_{i}$ & & & & $\begin{array}{l}0.871 \\
(.040)\end{array}$ & $\begin{array}{l}0.363 \\
(.193)\end{array}$ \\
\hline $\bar{R}^{2}$ & 0.99 & 0.99 & 0.03 & 0.93 & 0.93 \\
\hline DW & 0.58 & 1.03 & 1.89 & 1.47 & 1.85 \\
\hline
\end{tabular}

Standard error values in brackets 
Table 3.- Frontier convergence estimates for Germany, France and the United Kingdom. Estimates of the equation [6]. SUR method

The dependent variable is $\Delta \log A_{t+1}$

\begin{tabular}{lrrrrrrr}
\hline & Germany & France & United Kingdom & Germany & France & \multicolumn{2}{l}{ United Kingdom } \\
\hline$\delta$ & -0.118 & Common & Common & -0.171 & -0.208 & -0.103 \\
& $(.029)$ & & & $(.055)$ & $(.050)$ & $(.030)$ \\
$\lambda$ & 0.020 & 0.018 & 0.007 & 0.028 & 0.035 & -0.002 \\
& $(.005)$ & $(.006)$ & $(.005)$ & $(.010)$ & $(.009)$ & $(.006)$ \\
$\mu$ & 0.132 & Common & Common & 0.169 & Common & Common \\
& $(.014)$ & & & $(.025)$ & & \\
$\mathrm{R}^{2}$ & 0.52 & & & 0.54 & & \\
$\mathrm{DW}$ & 1.73 & & & & 1.79 & &
\end{tabular}

Standard error values in brackets. $\phi$ is not estimated here implicitly assuming it is equal to 1

Table 3 (Cont). - Frontier convergence estimates

Estimates of the equation [6]. SUR method

The dependent variable is $\Delta \log A_{t+1}$

\begin{tabular}{|c|c|c|c|c|c|c|c|c|}
\hline \multirow[b]{2}{*}{$\delta$} & \multirow{2}{*}{ Germany } & \multirow{2}{*}{$\begin{array}{l}\text { France } \\
\\
\\
-0.125 \\
(.034)\end{array}$} & \multicolumn{2}{|c|}{ United Kingdom } & \multirow{2}{*}{$\begin{array}{r}\text { Germany } \\
-0.252 \\
(.071)\end{array}$} & \multirow{2}{*}{ France } & \multicolumn{2}{|c|}{ United Kingdom } \\
\hline & & & In common & In common & & & $\begin{array}{r}-0.047 \\
(.095)\end{array}$ & $\begin{array}{r}-0.093 \\
(.043)\end{array}$ \\
\hline$\lambda$ & & $\begin{array}{l}0.019 \\
(.006)\end{array}$ & $\begin{array}{l}0.021 \\
(.006)\end{array}$ & $\begin{array}{r}-0.002 \\
(.007)\end{array}$ & $\begin{array}{l}0.041 \\
(.012)\end{array}$ & & $\begin{array}{l}0.007 \\
(.017)\end{array}$ & $\begin{array}{r}-0.002 \\
(.007)\end{array}$ \\
\hline$\mu$ & & $\begin{array}{c}0.149 \\
(.016)\end{array}$ & $\begin{array}{l}0.123 \\
(.019)\end{array}$ & $\begin{array}{l}0.195 \\
(.053)\end{array}$ & $\begin{array}{l}0.208 \\
(.033)\end{array}$ & & $\begin{array}{r}0.083 \\
(.050)\end{array}$ & $\begin{array}{c}0.151 \\
(.062)\end{array}$ \\
\hline $\mathrm{R}^{2}$ & & 0.54 & & & 0.55 & & & \\
\hline DW & & 1.79 & & & 1.87 & & & \\
\hline
\end{tabular}

Standard error values in brackets. $\phi$ is no estimated here implicitly assuming it is equal to 1 
Table 4.- Estimates of the impact of Log At The dependent variable is the residual of estimates in Table 3

\begin{tabular}{lcccc}
\hline & Germany & & France & United Kingdom \\
\hline & 1 & 2 & & \\
\hline & & & & \\
constant & 0.0171 & 0.0213 & 0.0100 & -0.0096 \\
& $(.008)$ & $(.009)$ & $(.009)$ & $(.022)$ \\
& & & & 0.0143 \\
$(\phi-1)$ & -0.0205 & -0.0275 & -0.0098 & $(.017)$ \\
& $(.006)$ & $(.006)$ & $(.006)$ & 0.002 \\
$\mathrm{R}^{2}$ & 0.17 & 0.26 & 0.03 & 1.64 \\
$D W$ & 1.79 & 1.63 & 1.69 & \\
\hline
\end{tabular}

Standard error values brackets 
(per cent of scientists and technicians in total employment)

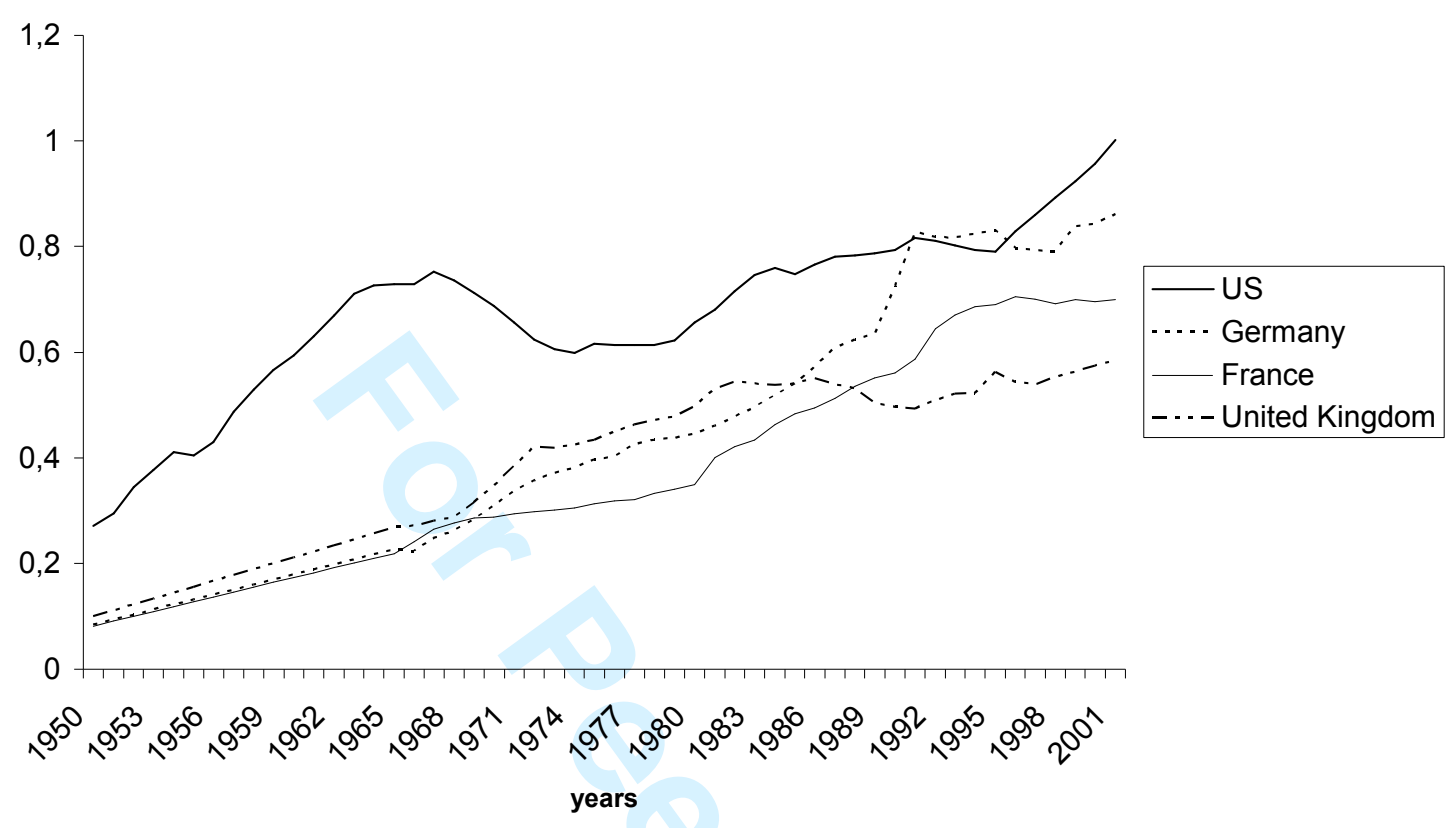

Source: Jones (2002) and own work 


\section{FIGURE 2.- TECHNOLOGICAL CAPITAL STOCK PER \\ RESEARCHER \\ Millions of 1995 euros per researcher}

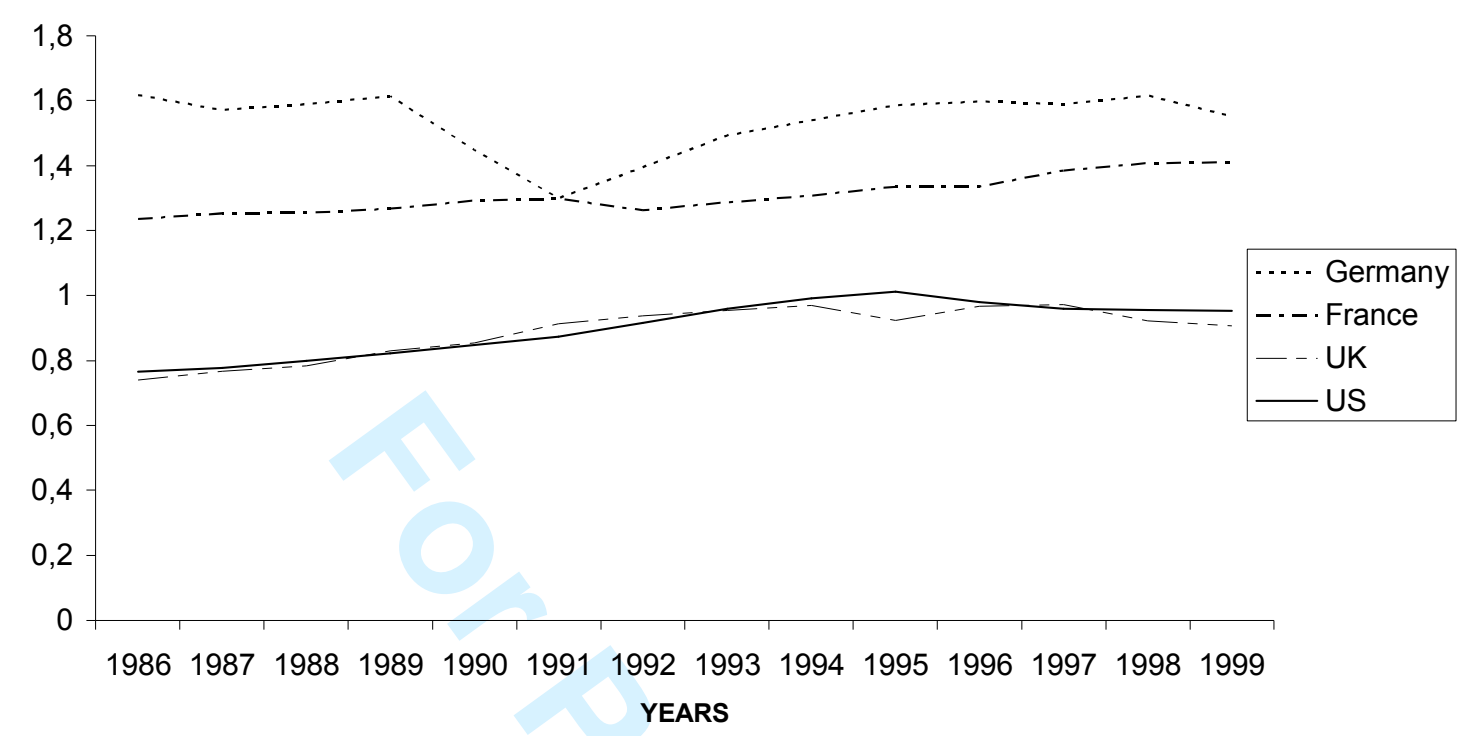

Source: Own work and Martín and Velázquez, 2001 
FIGURE 3. TOTAL FACTOR PRODUCTIVITY IN THE EUROPEAN

COUNTRIES: REAL AND ESTIMATES ANNUAL RATES

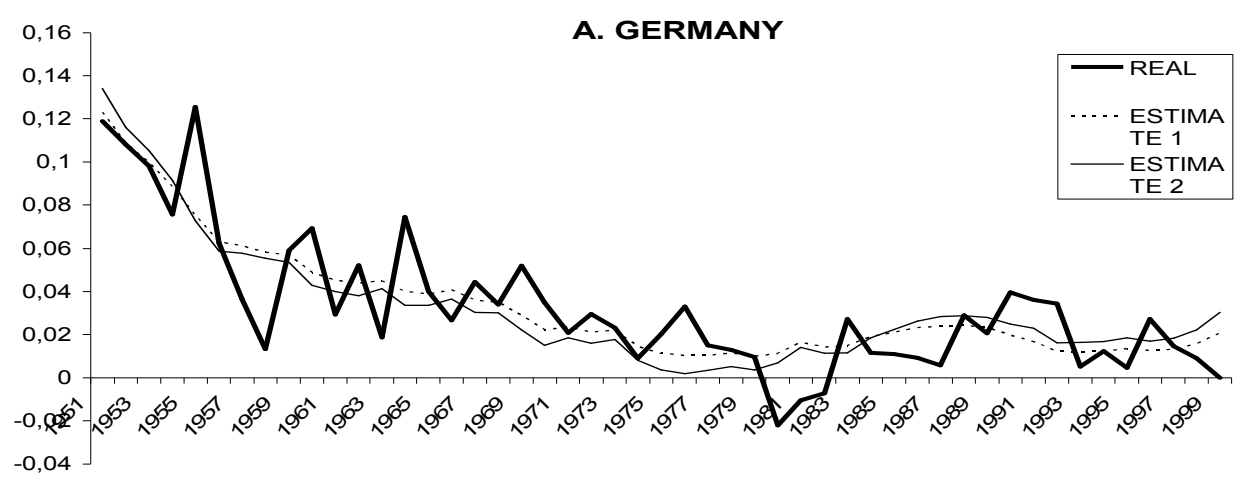

B. FRANCE

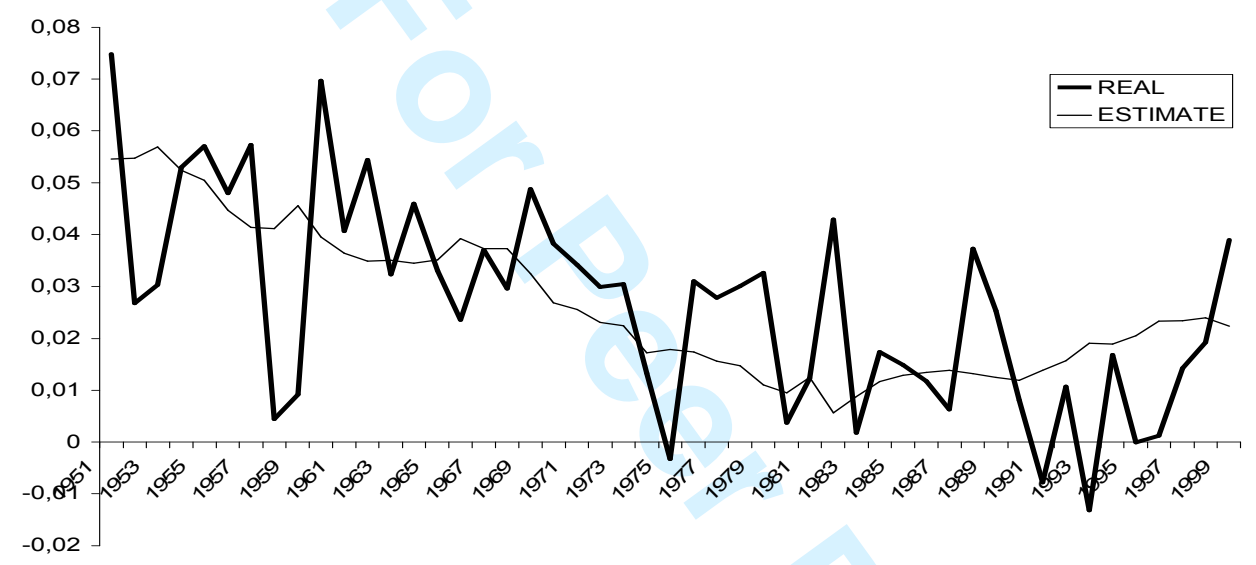

C. UNITED KINGDOM

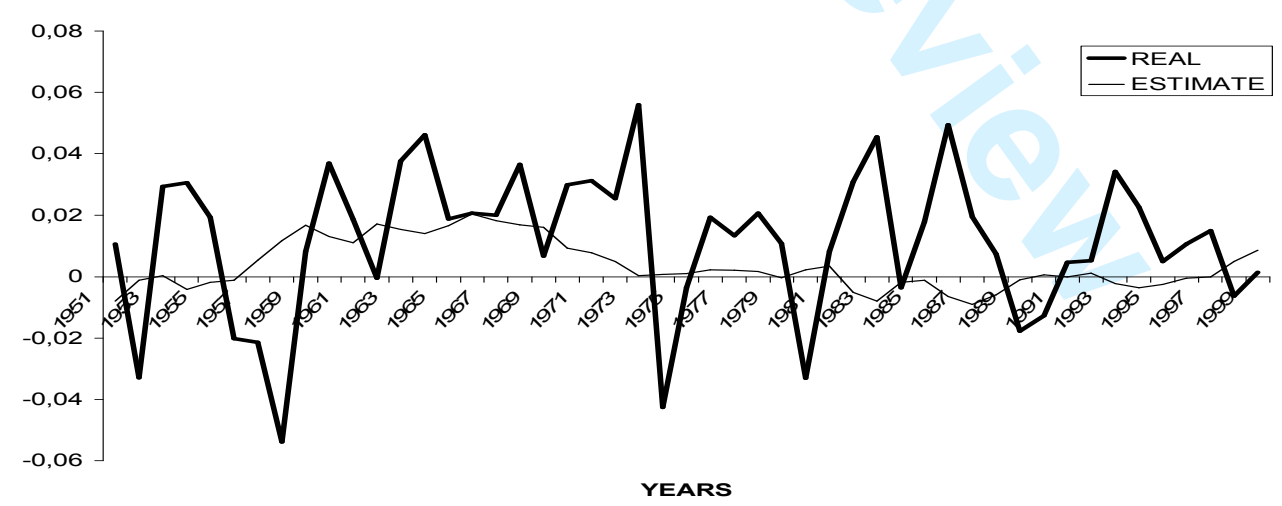

Source: Own work 